\title{
The extracellular phage-host interactions involved in the bacteriophage LL-H infection of Lactobacillus delbrueckii ssp. lactis ATCC 15808
}

\author{
Patricia Munsch-Alatossava and Tapani Alatossava* \\ Department of Food and Environmental Sciences, University of Helsinki, Helsinki, Finland
}

\author{
Edited by: \\ Jennifer Mahony, University College \\ Cork, Ireland \\ Reviewed by: \\ Olivia McAuliffe, Teagasc, Ireland \\ Marie-Pierre Chapot-Chartier, Institut \\ National pour la Recherche \\ Agronomique, France \\ ${ }^{*}$ Correspondence: \\ Tapani Alatossava, Department of \\ Food and Environmental Sciences, \\ University of Helsinki, P. O. Box 66, \\ Helsinki Fl-00014, Finland \\ e-mail: tapani.alatossava@helsinki.fi
}

The complete genome sequence of Lactobacillus bacteriophage LL-H was determined in 1996. Accordingly, LL-H has been used as a model phage for the infection of dairy Lactobacillus, specifically for thermophilic Lactobacillus delbrueckii ssp. lactis host strains, such as ATCC 15808. One of the major goals of phage LL-H research consisted of the characterization of the first phage-host interactions at the level of phage adsorption and phage DNA injection steps to determine effective and practical methods to minimize the risks associated with the appearance and attack of phages in the manufacture of yogurt, and Swiss or Italian hard type cheeses, which typically use thermophilic lactic acid bacteria starter cultures containing $L$. delbrueckii strains among others. This mini review article summarizes the present data concerning (i) the special features, particle structure, and components of phage LL-H and (ii) the structure and properties of lipoteichoic acids (LTAs), which are the phage LL-H receptor components of $L$. delbrueckii ssp. lactis host strains. Moreover, a model of the first, extracellular, phage-host interactions for the infection of L. delbrueckii ssp. lactis ATCC 15808 by phage LL-H is presented and further discussed.

Keywords: bacteriophage LL-H, lactic acid bacteria, Lactobacillus delbrueckii, lipoteichoic acid, phage receptor, antireceptor, phage adsorption, phage-host interaction

\section{INTRODUCTION}

The food industry benefits from the use of microbes as "work horses" in food processing, which contribute to the texture, chemical, and sensory properties of final food products. Lactic acid bacteria (LAB) are perhaps the most common bacteria applied as starter cultures for food manufacture. At an industrial scale, LAB starter-based lactic fermentations are performed in tanks with volumes of up to tens of cubic meters. The high number of starter cells comprising a single or a few strains makes these types of food processes highly susceptible to sudden appearance and attack of bacterial viruses, that is (bacterio)phages, and consequently increases the risk of the failure to control food fermentations and the quality of food products. LAB phages and phage resistance in LAB starter cultures have been intensively studied for decades because of the economic impact of the phage problems on the food industry. To obtain an in-depth scientific basis for the development of tools and approaches to minimize the risks of LAB phage infections in industrial food preparations associated with LAB fermentations, a better understanding of the origin, genetic diversity, and evolution of phages and phage biology, including phagehost interactions and phage resistance mechanisms (Samson et al., 2013), is needed.

The bacteriophage LL-H was isolated in 1972 from a whey sample originating from a problematic Emmental cheese production lot at a co-operative cheese processing plant in Hauho (Finland). The cheese starter culture employed at this dairy contained the Lactobacillus delbrueckii ssp. lactis (formerly L. lactis) strain LL23, which is sensitive to phage LL-H infection (Alatossava and Pyhtilä,
1980). Presently phage LL-H is one of the most thoroughly studied LAB phages and the first Lactobacillus phage, for which the complete genome sequence has been determined (Mikkonen, 1996; Mikkonen et al., 1996). Subsequently in the research, strain LL23 has been replaced with ATCC 15808, a more phage LL-H sensitive and widely available strain compared to LL23 strain.

\section{STRUCTURE OF PHAGE LL-H PARTICLE}

The results from electron microscopy (EM) studies on phage LL$\mathrm{H}$ have revealed that this phage represents the most common morphological group among phages having an icosahedral head (capsid coat containing compactly packed linear phage DNA) and a long, non-contractile tail. A small base plate and a flexible tail fiber are located at the end of the tail, as summarized in Figure 1 (Alatossava and Pyhtilä, 1980; Alatossava, 1987; Forsman and Alatossava, 1991; Forsman, 1994). Phage LL-H belongs to the pac-type phages comprising a linear ds-DNA molecule of approximately $38 \mathrm{~kb}$ with a $3 \mathrm{~kb}$ terminal repeat, packaged inside each phage capsid (Forsman and Alatossava, 1991). The linear LL-H DNA inside the capsid likely complexes with the divalent cations $\mathrm{Ca}^{2+}$ and/or $\mathrm{Mg}^{2+}$, which are co-transported into the cell as counterions of LL-H DNA during phage DNA injection (Alatossava, 1987; Alatossava et al., 1987). Phage LL-H particles are sensitive to Tris-buffer treatment (dialysis or gel filtration with Tris-buffer), which promotes in vitro phage DNA ejection (Alatossava, 1982). LL-H phages readily form clusters comprising filled and empty phage (ghost) particles connected together at the ends of the tails (Alatossava and Pyhtilä, 1980). 


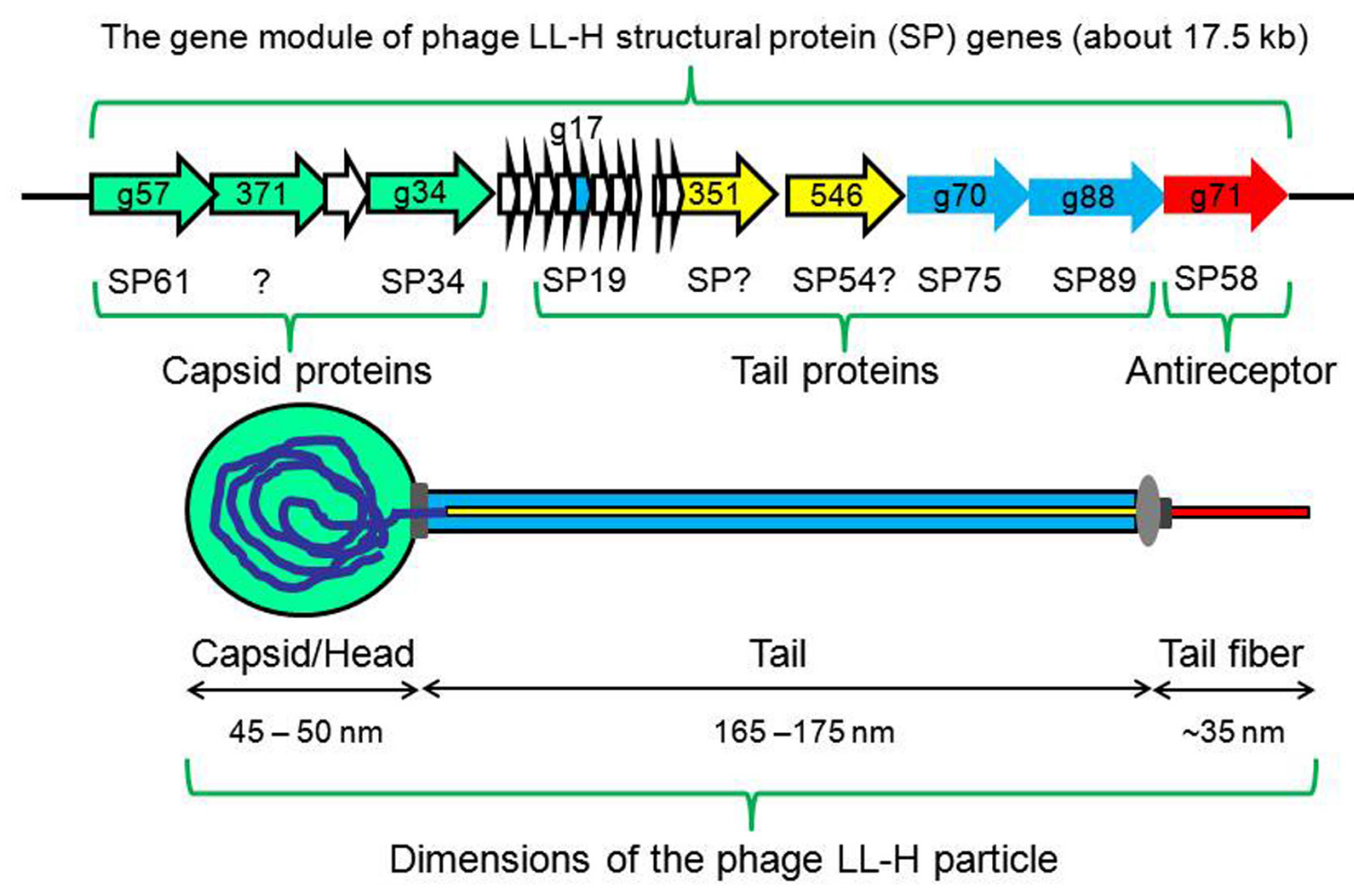

FIGURE 1 | Schematic diagram of phage LL-H particle. Genes encoding capsid and tail proteins are indicated as green and blue, respectively. Gene $g 71$ (red) encodes the antireceptor protein SP58. The proteins coded by genes orf351 and orf546 (yellow) are considered as tape measure protein (TMP) homologs, likely localized to the core of the tail. The base plate is indicated as gray.

Based on the SDS-PAGE analysis of twice-purified (by $\mathrm{CsCl}$ density gradient centrifugation) LL-H phage particles, nine different structural proteins of $89,75,61,58,54,34,23,19$, and $14 \mathrm{kDa}$ have been identified (Alatossava, 1987; Forsman and Alatossava, 1991). Among these, six phage structural proteins have been further characterized at the gene level (Figure 1): gene g34 encodes the major capsid protein SP34; gene $g 57$ encodes the minor capsid protein SP61; gene $g 17$ encodes the major tail protein SP19; genes $g 70$ and $g 88$ encode the two minor tail proteins, SP75 and SP89, respectively; and gene $g 71$ encodes the tail fiber antireceptor protein SP58 (Gp71) (Trautwetter et al., 1986; Vasala et al., 1993; Mikkonen and Alatossava, 1994; Vasala, 1998; Ravin et al., 2002). No phage genes have been identified for the 54, 23, and $14 \mathrm{kDa}$ LL-H structural proteins. These proteins may represent the proteolytic products of some other phage structural proteins or may be of bacterial origin. We re-sequenced the region between orf351 and orf360 described previously (Mikkonen and Alatossava, 1994; Mikkonen, 1996), and observed an additional G (GGG instead of GG) after the nt position 13888 (Mikkonen, 1996); consequently a single larger gene, orf546, was identified (Figure 1). Gene orf546 could potentially encode the observed structural protein SP54 that is present in the phage LL-H particle but is absent in the LL-H ghost particle (Trautwetter et al., 1986). The N-terminal domain of phage LL-H ORF351 (aa-residues 20-105) shows amino acid sequence homology with the domains of several phage tape measure proteins (TMP) including L. delbrueckii phage c5 putative TMP (Riipinen, 2011; Riipinen et al., 2011). In addition, the C-terminal end of phage LL-H ORF546 containing peptidoglycan (PG)-hydrolysing domain features, shows aa sequence homology with a putative TMP of L. delbrueckii phage JCL1032 (Riipinen, 2011; Riipinen et al., 2011). Accordingly, both ORF351 and ORF546 proteins have been localized to the core of the phage LL-H tail, similar to TMPs (Plisson et al., 2007). However, instead of a single multifunctional, large TMP (Boulanger et al., 2008), the TMP-associated PG-hydrolysing and cytoplasmic membrane (CM)-binding activities preceding phage DNA transfer are mediated through separate TMP homologs, proteins ORF546 (SP54?) and ORF351, respectively, in phage LL-H (Figure 1).

\section{STRUCTURE AND PHAGE RECEPTOR PROPERTIES OF Lactobacillus delbrueckii LIPOTEICHOIC ACIDS}

The first step of the phage infection cycle is the phage adsorption, the specificity of which is determined by the host bacterial surface component(s) and the phage component(s), receptor(s), and antireceptor(s), respectively. Furthermore, phage adsorption can be divided in two phases: a reversible phase and an irreversible phase. Among Gram-positive eubacteria, peptidoglycans, wall teichoic acids (WTA), lipoteichoic acids (LTA), and CM-associated proteins have been reported as phage receptor molecules. Proper genetic changes like spontaneous mutations affecting the structures of these molecules can prevent the adsorption of a particular phage and consequently increase the phage resistance of the 
mutated bacterial strain. However, the coevolution of phages with host bacteria facilitates mutations. For example, mutations in the antireceptor gene could change the host ranges of these mutant phages, and could potentially make the receptor mutant strains sensitive to the infections with these types of antireceptor phage mutants.

Both the phage receptor mutants of strain ATCC 15808 (the strain Ads-5) and the antireceptor mutants of phage LL-H (the strain LL-H-a21) have been isolated and further characterized (Ravin et al., 2002; Räisänen et al., 2004, 2007). The phage receptor mutant strain Ads-5 does not adsorb wild-type phage LL-H, but rather facilitates the effective adsorption of the host range phage mutants such as LL-H-a21. Each of the five host range phage mutants of LL-H studied contains a single nucleotide change at the $3^{\prime}$-end of gene $g 71$, which encodes a mutant protein with a single aa substitution (Asn to Lys, Ala to Ser, or Gln to His) in the C-terminal end [in the region 380-543 aa of the 656 aa-protein SP58 (Gp71)]. Consequently, $g 71$ has been designated as the antireceptor-encoding gene. The structural analyses of LTAs from ATCC 15808 and Ads-5, the phage receptor mutant strain of ATCC 15808 , have revealed a significant difference: the polyglycerolphosphate backbone of the LTA from Ads- 5 lacks the single glucose moiety located most probably at the surface end of the LTA from ATCC 15808. Other structural features of LTAs, such as the levels of D-alanylation, average numbers of glycerolphosphate repeats, and the ratios and compositions of fatty acids linked to the triglucose moiety of the glycolipid anchor were not changed (Räisänen et al., 2007). The results of phage inactivation studies using purified LTA preparations suggest that the surface glucose substituted LTA is required for the specific reversible adsorption and enough free, nonsubstituted glycerol residues (allowing local negative charge in the LTA backbone) for the irreversible adsorption of wild-type LL-H. For the host range phage LL-H mutants, both the surface glucose-substituted and surface glucose-free forms of LTAs are equally functional as phage receptors (Räisänen, 2007). Thus, the extension of the host range may occur at the expense of the specificity of the phage receptor.

\section{A MODEL OF PHAGE LL-H ANTIRECEPTOR - HOST LTA INTERACTIONS}

The structural properties of the phage LL-H particle and the genetic, biochemical, and electron microscopic data on the phage LL-H antireceptor/fiber, the ATCC 15808 LTA as phage receptor, and the phage LL-H infectivity and stability properties suggest, for

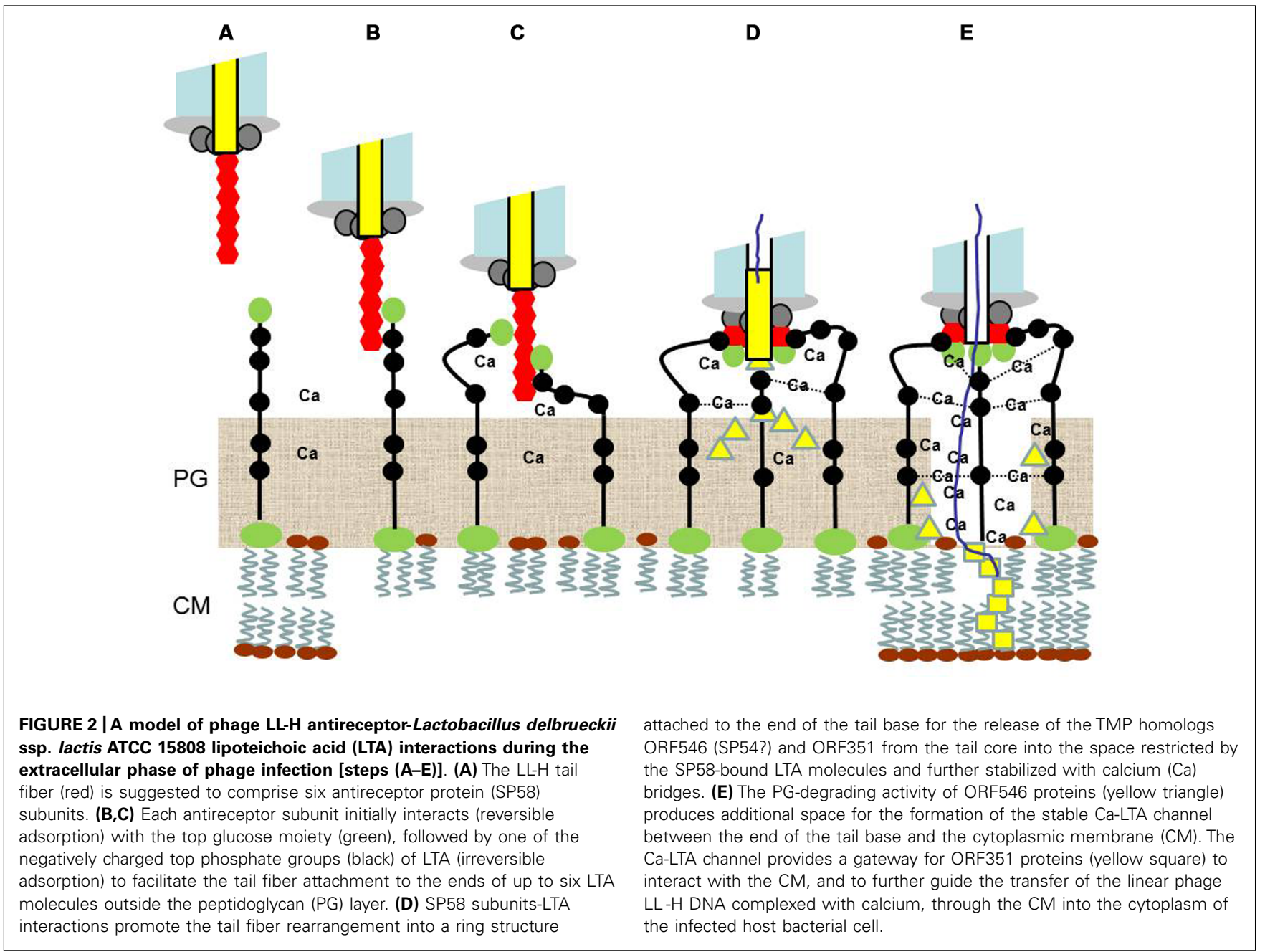


the extracellular interactions between phage LL-H antireceptor and LTAs of the ATCC1 5808 host strain, a model described in Figure 2. The tail fiber, which is approximately $35 \mathrm{~nm}$ in length (Forsman and Alatossava, 1991; Forsman, 1994), is considered as a flexible hexapolymer of the antireceptor protein SP58 encoded by gene $g 71$ of phage LL-H. The C-terminal end of each antireceptor protein subunit contains one domain responsible for the reversible, specificity-determining binding to the surface end of the LTA, primarily mediated through hydrogen bonds to the glucose moiety. The second domain of the antireceptor protein SP58 ensures the irreversible binding to the negatively charged glycerol phosphate group(s) (no or low local D-Alanylation of glycerol phosphate repeats) close to the surface end of the LTA, possibly mediated through ionic bonds. Altogether, up to six LTA molecules can bind to the single phage tail fiber, promoting the rearrangement of the fiber to form a ring structure with a maximum diameter of $11 \mathrm{~nm}$ (i.e., $35 \mathrm{~nm} / \pi$ ) attached to the tail base by the interactions of the six antireceptor protein subunits. The occurrence of the phage tail end-LTAs complexes could explain the observed heterogeneous structures and clusters of phage tail ends of negatively stained LL-H phage and empty LL-H ghost particles (e.g., Alatossava and Pyhtilä, 1980). The ring arrangement of the six antireceptor subunits suggests that the TMP homologs ORF546 (SP54?) and ORF351 are released from the core of the tail before the release of linear phage DNA. The muranolytic activity of ORF546 degrades PG inside the space of the LTA molecules (up to six) attached to the hexameric antireceptor (SP58) ring, facilitating the free movement of these attached LTA molecules and the subsequent formation of a stable calcium-LTA channel between the tail base end and CM as a tail extension. Phage LL-H infectivity is highly dependent on the external calcium or magnesium concentration, with an optimum of nearly the $\mathrm{Ca} / \mathrm{Mg}$ solubility limits of the medium, 20-40 mM, which is approximately one log-unit higher than the $\mathrm{Ca} / \mathrm{Mg}$ optimum required for phage LL-H adsorption (Alatossava, 1987). Accordingly, the requirements for Ca-LTA channel formation could reflect the observed high external calcium (or alternatively magnesium) concentration for optimal phage LL-H infectivity. Moreover, the proposed Ca-LTA channel would act as a gateway to the CM for ORF351, which contains two putative transmembrane motifs (residue regions 140-170 and 250-270) following the N-terminal tape measure domain. These interactions are likely required for the successful and effective transfer of linear phage DNA as a Ca-complex through the CM into the cytoplasm. The observed m.o.i. (multiplicity of infection)dependent influx of calcium into the infected cell during the first minutes of phage infection (Alatossava et al., 1987) supports this model.

\section{PERSPECTIVE}

A model of the extracellular interactions between the phage antireceptor and LTA receptors of the host has been proposed. The suggested formation of a stable calcium-LTA channel as the connecting structure between the phage LL-H tail base and the host $\mathrm{CM}$ could reflect the observed high calcium dependency for optimal LL-H infectivity. The Ca-LTA channel formation could exist not only in the case of phage LL-H, but also more generally among
Gram-positive Ca-dependent phages, which do not contain phage lysin as an external structural tail base component.

\section{ACKNOWLEDGMENTS}

This work was supported through a grant (received on September 25, 2012) from the Finnish Cultural Foundation to Tapani Alatossava.

\section{REFERENCES}

Alatossava, T. (1982). Factors affecting in vitro DNA ejection of the Lactobacillus lactis bacteriophage LL-H. J. Gen. Virol. 59, 173-175. doi: 10.1099/0022-1317-59$1-173$

Alatossava, T. (1987). Molecular Biology of Lactobacillus lactis Bacteriophage LL-H (Vol. A191). Ph.D. thesis, Acta Universitatis Ouluensis, Oulu.

Alatossava, T., and Pyhtilä, M. J. (1980). Characterization of a new Lactobacillus lactis bacteriophage. IRCS Med. Sci. 8, 297-298.

Alatossava, T., Jütte, H., and Seiler, H. (1987). Transmembrane cation movements during infection of Lactobacillus lactis by bacteriophage LL-H. J. Gen. Virol. 68, 1525-1532. doi: 10.1099/0022-1317-68-6-1525

Boulanger, P., Jacquot, P., Plancon, L., Chami, M., Engel, A., Parquet, C., et al. (2008). Phage T5 straight tail fiber is a multifunctional protein acting as a tape measure and carrying fusogenic and muralytic activities. J. Biol. Chem. 283, 13556-13564. doi: 10.1074/jbc.M800052200

Forsman, P. (1994). Genetic Variation and Evolution of Bacteriophages of Lactobacilli (Vol. A257). Ph.D. thesis, Acta Universitatis Ouluensis, Oulu.

Forsman, P., and Alatossava, T. (1991). Genetic variation of Lactobacillus delbrueckii subsp. lactis bacteriophages isolated from cheese processing plants in Finland. Appl. Environ. Microbiol. 57, 1805-1812.

Mikkonen, M. (1996). Genes and Genomes of Lactobacillus Phage LL-H (Vol. A281). Ph.D. thesis. Acta Universitatis Ouluensis, Oulu.

Mikkonen, M., and Alatossava, T. (1994). Characterization of the genome region encoding structural proteins of Lactobacillus delbrueckii subsp. lactis bacteriophage LL-H. Gene 151, 53-59. doi: 10.1016/0378-1119(94)90632-7

Mikkonen, M., Räisänen, L., and Alatossava, T. (1996). The early gene region completes the nucleotide sequence of Lactobacillus delbrueckii subsp. lactis phage LL-H. Gene 175, 49-57. doi: 10.1016/0378-1119(96)00119-9

Plisson, C., White, H. E., Auzat, I., Zafarani, A., Sao-Jose, C., Lhuillier, S., et al. (2007). Structure of bacteriophage SPP1 tail reveals trigger for DNA ejection. EMBO J. 26, 3720-3728. doi: 10.1038/sj.emboj.7601786

Ravin, V., Räisänen, L., and Alatossava, T. (2002). A conserved C-terminal region in Gp71 of the small isometric-head phage LL-H and ORF474 of the prolate-head phage JCL1032 is implicated in specificity of adsorption of its host, Lactobacillus delbrueckii. J. Bacteriol. 184, 2455-2459. doi: 10.1128/JB.184.9.2455-2459. 2002

Riipinen, K.-A. (2011). Genetic Variation and Evolution Among Industrially Important Lactobacillus Bacteriophages (Vol. A589). Ph.D. thesis, Acta Universitatis Ouluensis, Oulu.

Riipinen, K.-A., Forsman, P., and Alatossava, T. (2011). The genomes and comparative genomics of Lactobacillus delbrueckii phages. Arch. Virol. 156, 1217-1233. doi: 10.1007/s00705-011-0980-5

Räisänen, L. (2007). Phage-Host Interactions in Lactobacillus delbrueckii: Host Recognition and Transcription of Early Phage Genes (Vol. A315). Ph.D. thesis, Acta Universitatis Ouluensis, Oulu.

Räisänen, L., Schubert, K., Jaakonsaari, T., and Alatossava, T. (2004). Characterization of lioteichoic acids as Lactobacillus delbrueckii phage receptor components. J. Bacteriol. 186, 5529-5532. doi: 10.1128/JB.186.16.5529-5532.2004

Räisänen, L., Draing, C., Pfitzenmaier, M., Schubert, K., Jaakonsaari, T., von Aulock, S., et al. (2007). Molecular interaction between lipoteichoic acids and Lactobacillus delbrueckii phages depends on D-Alanyl and $\alpha$-Glucose substitution of poly(glycerophosphate) backbones. J. Bacteriol. 189, 4135-4140. doi: 10.1128/JB.00078-07

Samson, J. E., Magadán, A. H., Sabri, M., and Moineau, S. (2013). Revenge of the phages: defeating bacterial defences. Nat. Rev. Microbiol. 11, 675-687. doi: 10.1038/nrmicro3096

Trautwetter, A., Ritzenthaler, P., Alatossava, T., and Mata-Gilsinger, M. (1986). Physical and genetic characterization of the genome of Lactobacillus lactis bacteriophage LL-H. J. Virol. 59, 551-555. 
Vasala, A. (1998). Characterization of Lactobacillus bacteriophage LL-H Genes and Proteins Having Biotechnological Interest (Vol. A315), Ph.D. thesis. Acta Universitatis Ouluensis, Oulu.

Vasala, A., Dupont, L., Baumann, M., Ritzenthaler, P., and Alatossava, T. (1993). Molecular comparison of the structural proteins encoding gene clusters of two related Lactobacillus delbrueckii bacteriophages. J. Virol. 67, 3061-3068.

Conflict of Interest Statement: The authors declare that the research was conducted in the absence of any commercial or financial relationships that could be construed as a potential conflict of interest.

Received: 29 October 2013; accepted: 10 December 2013; published online: 24 December 2013.
Citation: Munsch-Alatossava $P$ and Alatossava $T$ (2013) The extracellular phagehost interactions involved in the bacteriophage $L L-H$ infection of Lactobacillus delbrueckii ssp. lactis ATCC 15808. Front. Microbiol. 4:408. doi: 10.3389/fmicb.2013. 00408

This article was submitted to Virology, a section of the journal Frontiers in Microbiology.

Copyright (c) 2013 Munsch-Alatossava and Alatossava. This is an open-access article distributed under the terms of the Creative Commons Attribution License (CC BY). The use, distribution or reproduction in other forums is permitted, provided the original author(s) or licensor are credited and that the original publication in this journal is cited, in accordance with accepted academic practice. No use, distribution or reproduction is permitted which does not comply with these terms. 